\title{
Inquiry-Based Learning in Theology
}

\author{
Oliver Reis
}

\subsection{Characteristic Features in the Field of Theology as a Constraint on Inquiry-Based Learning}

Theology as a scholarly discipline exists only in a plurality of denominations, which is because theology in Germany is taught from a denominational perspective due to the teachings of the church. For this reason, churches grant individual instructors permission to teach, and also separately approve of the degree programs through accreditation procedures. In Germany, theology is distinguished by its position, situated between teaching in academic freedom while at the same time doing so on behalf of the church. Theology is not a study of religion, but rather the reflective and methodological engagement with the beliefs of a religious community from within the same religious community. Theological research therefore does not investigate God, which would overwhelm theology. Instead, it deals with the human testimonies of faith for the believers. Theology has developed significantly during the course of its more than 2000-year history. An early form of theology is apologetics, which shows that the Christian faith is compatible with ancient philosophies during the period in which Christians were persecuted. Another is dogmatism, which seeks to rationalize questions of faith according to internal standards in times of differences of faith.

Today, four theological subject groups have become established, ensuring an extremely high level of internal cultural diversity. This also has an impact in terms of research methodology: Thus

O. Reis, Dr. Dr. $(\bowtie)$

Universität Paderborn, Institut für Katholische Theologie, Professur für Religionspädagogik mit dem Schwerpunkt der Inklusion, Paderborn, Germany

e-mail: oliver.reis@uni-paderborn.de

H. A. Mieg (ed.), Inquiry-Based Learning - Undergraduate Research, https://doi.org/10.1007/978-3-030-14223-0_32 
- biblical theology is methodologically oriented towards literary studies and cultural studies,

- historical theology is oriented towards the work of reconstructing historical source materials,

- systematic theology is oriented towards classic hermeneutics within the humanities

- and practical theology is oriented towards empirical educational sciences.

This results in completely different teaching and research traditions, which tolerate one another, but which also observe each other critically.

In the theological teaching practiced in Germany, a great deal of skepticism can be observed towards the Bologna study reform and adapting material for didactics in general. Without idealizing pre-Bologna conditions, engineered ideas about the feasibility of learning tend to be rejected in theology. Each new higher education didactic concept is tested for its impact on freedom of thought and the free educational development of the individual. This emphasis on freedom is connected with the above-mentioned position of the church, but also with the fact that the faith of the individual as well as God himself cannot and must not be controlled for us. The theological subjects must deal with this unavailability methodically. A subject area such as dogmatic theology within systematic theology is going to have a much harder time understanding its own teaching as a didactic locus than, for example, religious education, which can more easily relate its subject-the people learning before God-to its own teachings.

Despite the confessional and professional diversity, theology has individual actors with a clear interest in didactic innovation of higher education, which can emphasize the main points in individual teaching projects and modules, depending on the situation on site at the specific institutions of higher learning. Theologians are involved in their own projects and use institutional support at the German institutions of higher learning that offer theological instruction, and that are committed to inquiry-based learning in a programmatic way. In some cases this has also led to the curricular anchoring of inquiry-based learning, for example in the master's degree program "Christentum in Kultur und Gesellschaft" "“Christianity in Culture and Society") at the University of Münster or in the master's module "Theologische Forschung" ("Theological Research") at the Technical University of Dortmund.

Due to the mentioned basic conditions, there is no systematic reception of inquirybased learning in theology. The principle is received differently in the various denominations and in the subject areas, and is filled with different research ideas. Unlike principles such as competence orientation, the ideological resistance to inquiry-based learning has diminished because in theology inquiry-based learning is understood as a counter-impulse to school-like and mechanized learning. This facilitates the actor's reception in two contexts: (a) the training of religious instructors with a focus on the theory-practice problem that imparting subject-specific content leaves hardly any traces in the educational reality of religious instruction (cf. Zimmermann and Lenhard 2015, pp. 15-18), or (b) master's modules in the former theological degree programs awarding a Diplom, which are consciously conceived as free learning places in contrast to the perceived reduction of education by the Bologna process to the level of school instruction. 


\subsection{Experiences with Inquiry-Based Learning in Theology}

\subsubsection{Inquiry-Based Learning-An Attempt to Structure the Formats}

What exactly is it that should be investigated under the heading "inquiry-based learning" in the discipline of theology? In order to be able to sort the individual phenomena, I would first like to merge the structuring of Huber (2014) and Reinmann (in this volume).

Huber makes a distinction between research-based learning (forschungsbasiertes Lernen), research-oriented learning (forschungsorientiertes Lernen) and inquiry-based learning (Forschendes Lernen). In his structuring, increasing participation in the complete research process is the guiding interest of those involved in the process. Research-based learning (or, better yet, research-based teaching [Ludwig 2011]?) orients teaching, and thus learning as well, towards students' existing research interests. This is reflected in the way in which the discipline teaches its research-related aspect. Research-oriented learning goes beyond an orientation towards research-relevant issues and includes a methodological processing of the question based on professional standards. Beyond the question and its method-guided processing, inquiry-based learning also emphasizes evaluation and presentation to third parties. Here it becomes clear that research always happens within a specific context. For Huber, even inquiry-based learning need not be objectively innovative; it is a learning process within the context of scholarship that is innovative for the individual. On the other hand, when Reinmann distinguishes between "understanding research," "practicing research" and "performing researching oneself," she discovers an order of competency development between the poles of receptivity and productivity. It is productive, in my opinion, not to parallelize the two orders, as proposed by Reinmann (cf. Reinmann 2015, p. 5), but to intersect them (see Fig. 32.1).

Huber distinguishes among phases of the research process, thus the subject matter, and Reinmann distinguishes among phases of the development process, thus the activity with the subject matter. In between, there are some relevant intermediate moments that are significant for theology. Thus, for example, it is possible to focus on the development of one's own technically workable question, i.e. to strive for research-based learning within the meaning of Huber, and to put this into a supported pre- and post-process, thereby emphasizing the receptivity and productivity equally, which corresponds to Reinmann's approach to practice research (cf. X1 in Fig. 32.1). At the end of the bachelor's degree, it would also be possible to make inquiry-based learning in the sense of Huber's knowledgebased object (as "understanding research" in the sense of Reinmann) a course that should help in the choice between an application- or research-oriented master's degree (cf. X2 in Fig. 32.1). Of course, the ideal goal would be for both orders to come together as students conduct their own research throughout the process. To capture the reality of theology, however, the focus is on the intermediate stages. 


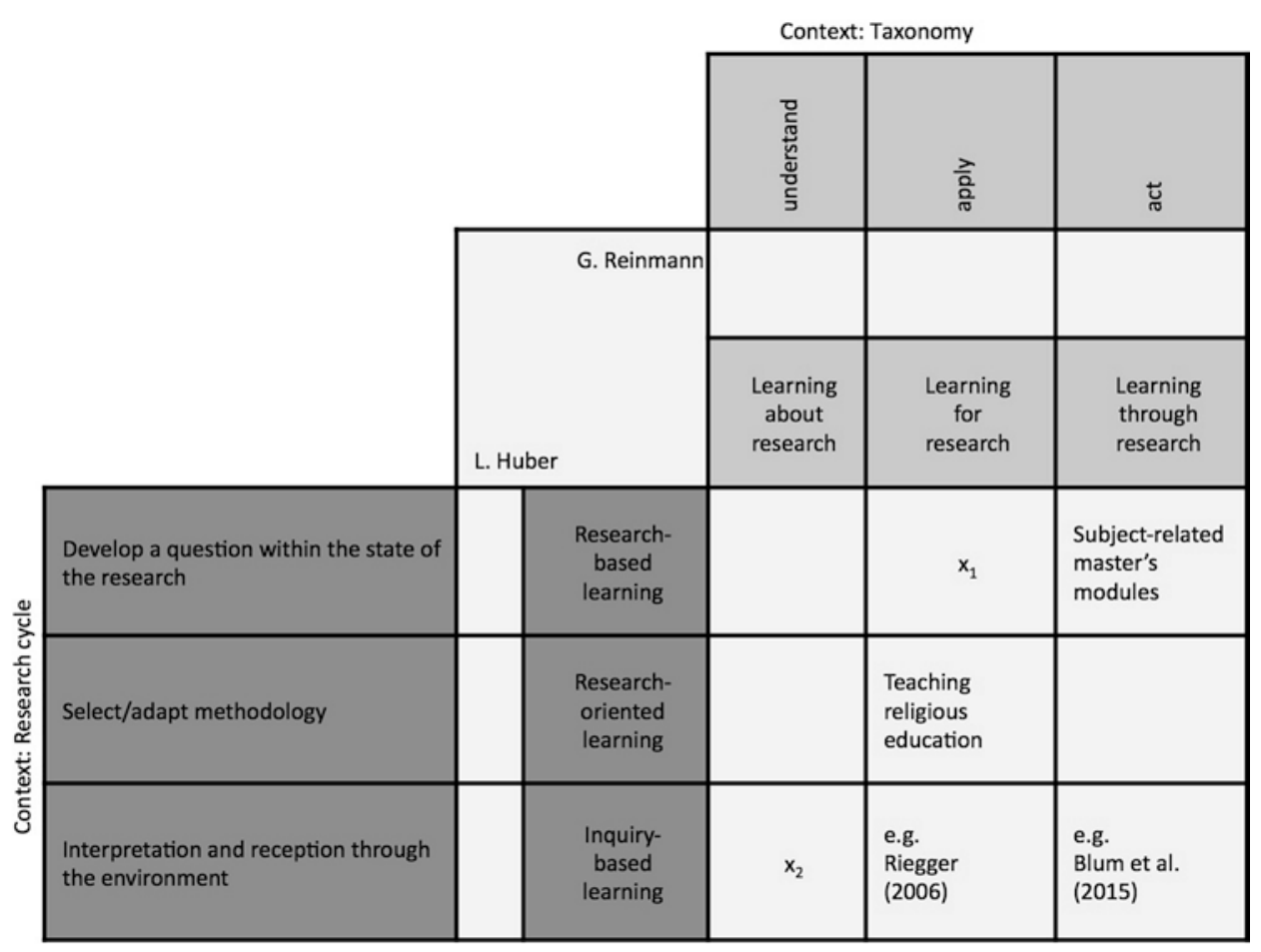

Fig. 32.1 Matrix of inquiry-based learning. (Source: author's representation) according to Huber (2014) and Reinmann (in this volume)

\subsubsection{Formats in Theology}

\subsubsection{Link Between Theory and Practice in the Education of Religious Education Teachers}

The training of religious education teachers includes various teaching projects that use inquiry-based learning in religious education courses to support internships or a whole practical semester.

The following projects exist in Protestant theology: In the case of Petra FreudenbergerLötz at the University of Kassel, students conduct religious education and evaluate it according to the grounded theory research concept (cf. Freudenberger-Lötz 2007; Schmidl 2012). Heinz Streibl, at the University of Bielefeld, attaches great importance to class observation that is oriented towards the research cycle. At the University of Osnabrück, Caroline Teschner develops independent research questions with the students within the framework of action research; these questions influence the teaching design as guiding theses.

In terms of Catholic theology, the following examples can be mentioned: Guido Hunze works with video-based reflection talks and peer learning at the University of Münster (cf. Hunze 2010, pp. 257-259). At the University of Würzburg, Boris Kalbheim develops 
criteria for material analysis with students, conducts these analyses and has developed material for religious education (cf. Kalbheim 2013, pp. 203-206). Regine Oberle allows students at the Heidelberg University of Education to present their pupils' ideas on specific topics along the research cycle in order to improve subject orientation in religious education. In the case of Manfred Riegger from the University of Augsburg, students generate hypotheses through participatory observations that become relevant to classroom practice (cf. Riegger 2006).

Inquiry-based learning is used as a large-scale method to observe this in practice using research-oriented behavior, and to refer it back both to the theory of didactics and to religious didactic theory formation. Generally, the research cycle is not taught; instead, students in the practical phase are expected to apply the research cycle and generate results. Research reports often document and reflect on this research experience. This format can easily be construed as research-oriented learning in that research is pursued for the professionalization in the field of action. For inquiry-based learning, the contextual feedback of the results is usually missing. The results are not systematically evaluated and communicated in the teaching contexts or used for further development of the individual study biography, for example. The issue is about passing through the cycle itself and the associated research-oriented behavior, which raises awareness about which processes take place in religious education, how they are to be understood theologically and didactically, and which options for action arise therefrom. Furthermore, the self-determined framework for independent research is lacking. The didactic guidelines are tightly set in these teaching projects. The "Specialization Module Specialist Didactics: Religion, Bildung, Schule, Professionskunde" ("In-depth module for teaching methodology: religion, education, school, study of professions") of the Master of Education at the University of Münster is an example of how research-oriented learning can now be institutionally anchored in the training of religious instructors as a "practical obstacle course" (cf. "Religious Teachers inside education" in Fig. 32.1).

Individual examples go a step further and ensure that the research results are made available to the specialist discourses. Particularly productive is the Kasseler research workshop, with its own publication series, "Beiträge zur Kinder- und Jugendtheologie" ("Contributions to child and youth theology"). Others take up the research results in order to directly influence the practice of action (for example in the case of Manfred Riegger in Augsburg, cf. Riegger 2006). In these examples, the entire process (of inquiry-based learning) is practiced.

\subsubsection{Professional Courses with a Research Assignment}

If inquiry-based learning is used in the subject modules, students should be given the opportunity to carry out independent learning processes. Usually, such research projects are assigned to the individual theological subjects. What is noticeable is that many projects can be identified in church history, e.g. at Ruhr University Bochum, the University of Oldenburg or the University of Tübingen. At the same time, there are projects in practical theology, for example at the University of Leipzig or the University of Frankfurt. The 
degree of support may fluctuate, but neither topics nor methodologies are specified; developing them is part of the project. The focus is on the discovery of a research-related question and its experimental work in a self-guided learning process in the sense of "self-research." When such modules are evaluated, the methodology is evaluated, but not as clearly as in the bachelor's and master's thesis. This is possible because it can be assumed that the students possess the essential knowledge and methodological skills. But that does not mean that the students are comprehensively informed about the concept of inquiry-based learning or that process itself was practiced. Inquiry-based learning remains rather implicit, while for students, the freedom needed for independent engagement with a personally relevant question is at the fore (cf. "Subject-related master modules" in Fig. 32.1).

This leads to the results being structurally continued (e.g. within the curriculum) in theses in only a few examples. This happens at the University of Münster and the University of Dortmund, for example. In some cases, the result is so innovative from the outset that it is brought to the public, as provided in the subject of church history at the University of Bochum and the University of Tübingen. The professional handling of the question then becomes important, in order for the result to be able to withstand public pressure.

\subsection{Sample Implementation of Inquiry-Based Learning}

In the following, I would like to present an example of a consistent orientation towards inquiry-based learning (see Fig. 32.1). In this presentation, I focus on the sequence of learning steps, which clearly shows how the research work is introduced in the teaching project, supported and used for further steps. The classification in the matrix (Fig. 32.1) takes place within the representation (see Table 32.1).

\subsection{Outlook for Inquiry-Based Learning in Theology: What Needs to Be Done?}

An essential task will be to network the previous approaches to inquiry-based learning in theology. Due to the confessional boundaries and the diversity of the subject cultures, the actors barely acknowledge one another and do not relate to one another. Usually, didactic approaches from general higher education are adopted and applied; however, a separate didactic discourse is still needed. Yet inquiry-based learning in particular has the potential to make theology more widely available to university didactics, since it does not involve a reputation for further reducing higher education to the level of school instruction or for stripping away the emphasis on expertise in the subject.

Looking at the Table 32.1, it is clear that only a percentage of the formats has found a place in theology and that, above all, "understanding research" is still not as well integrated into the projects. If inquiry-based learning continues to be implemented within the 
Table 32.1 Project: Sifting through original sources, sorting and writing the history of German post-war Catholicism; research on church history projects (cf. also Blum et al. 2015). Guidance: Daniela Blum (University of Tübingen), Florian Bock (University of Tübingen) and Andreas Henkelmann (Ruhr University Bochum)

\begin{tabular}{|c|c|}
\hline Step 1 & \multirow{2}{*}{$\begin{array}{l}\text { Initially, several introductory sessions on post-war Catholic history and } \\
\text { recurring tutorials on source study/analysis are offered. On the thematic } \\
\text { level, the historical context in southwestern Germany is introduced. }\end{array}$} \\
\hline $\begin{array}{l}\text { Students develop a } \\
\text { thematic body of } \\
\text { knowledge. They } \\
\text { practice in historical } \\
\text { source analysis. }\end{array}$ & \\
\hline Step 2 & \multirow[b]{2}{*}{$\begin{array}{l}\text { The joint training phase does not end with the material, but instead leads } \\
\text { to codified archival practices, and thus to methodological competence, } \\
\text { which students try out on practical examples (finding aids, etc.). The } \\
\text { question for lecturers is what must be learned thematically and } \\
\text { methodically in order to start the first archive phase. Lecturers take the } \\
\text { liberty of deviating from some aspects of the seminar plan and dealing } \\
\text { with other aspects in detail, if the research processes make this necessary. }\end{array}$} \\
\hline $\begin{array}{l}\text { Students become } \\
\text { familiar with the } \\
\text { method of working } \\
\text { with the archive. }\end{array}$ & \\
\hline Step 3 & \multirow[b]{2}{*}{$\begin{array}{l}\text { During the preparation phase, students form small groups to analyze } \\
\text { source materials (files, minutes, etc.) for a self-developed historical } \\
\text { question. There is a strong emphasis on the autonomous allocation of } \\
\text { time and work by students. The development phase begins with a visit to } \\
\text { the Diocesan Archives in Rottenburg. This is followed by a critical } \\
\text { evaluation of the materials, whereby special emphasis is placed on } \\
\text { freedom and independence in the finding of knowledge: Students find } \\
\text { new source material, read it, develop a research question in view of the } \\
\text { current state of the research, read the sources again in view of the } \\
\text { research question, investigate other, possibly edited sources or secondary } \\
\text { literature in the event that contexts are unclear, and create their own } \\
\text { image in answering the question using the various building blocks of } \\
\text { secondary literature and sources. }\end{array}$} \\
\hline $\begin{array}{l}\text { Students develop their } \\
\text { own research } \\
\text { questions through } \\
\text { independent archival } \\
\text { work and literature } \\
\text { research. }\end{array}$ & \\
\hline Step 4 & \multirow[b]{2}{*}{$\begin{array}{l}\text { In the midst of this preparation phase, a group session is held. The aim of } \\
\text { this session is to "stop" the initiated learning process in order to reflect } \\
\text { on it in terms of learning barriers. At the same time, it is about } \\
\text { intensively discussing the key questions, as these are the starting point } \\
\text { for further development. Without a key question, the search horizon } \\
\text { cannot be reduced to a level that can be implemented with the seminar. } \\
\text { The groups talk intensively about their experiences and results. Fellow } \\
\text { students, not the lecturers, point out possible solutions for practical and } \\
\text { content-related problems and act as experts on the level of question, } \\
\text { subject and methodological competence. }\end{array}$} \\
\hline $\begin{array}{l}\text { Students articulate } \\
\text { and reflect on the } \\
\text { ambiguities or } \\
\text { problems resulting } \\
\text { from step } 3 .\end{array}$ & \\
\hline Step 5 & \multirow[b]{2}{*}{$\begin{array}{l}\text { This is followed by the second phase of on-site preparation. This phase is } \\
\text { similar in a central point of the first phase, namely the source reading } \\
\text { material. However, this reading should now refer specifically to the key } \\
\text { question, however. This is done in the form of a literature search to } \\
\text { contextualize the sources. The actual source analyses are subsequently } \\
\text { conducted. Literature research and source analysis are therefore mutually } \\
\text { dependent. As such, it is a circular process, not a linear one. }\end{array}$} \\
\hline $\begin{array}{l}\text { Students coordinate } \\
\text { the key question, } \\
\text { source analysis and } \\
\text { literature research and } \\
\text { construct a narrative } \\
\text { about the self- } \\
\text { developed question. }\end{array}$ & \\
\hline
\end{tabular}


Table 32.1 (continued)

\begin{tabular}{l|l}
\hline Step 6 & $\begin{array}{l}\text { At the end of the semester, the individual teams present their answers to } \\
\text { the seminar in a final session. For the additional proof of performance in } \\
\text { Students prepare their } \\
\text { results for their target } \\
\text { group and feed their } \\
\text { narrative into a } \\
\text { cultural context. }\end{array}$ \\
$\begin{array}{l}\text { presentations are prepared in the form of a newspaper article for the } \\
\text { diocese newspaper ("Zeitschnitte" ["Cross-sections of time"] series in } \\
\text { the Rottenburg Sonntagsblatt) or a scientific paper. In addition to } \\
\text { sharpening the historical view of one's own local environment, the issue } \\
\text { of perspective analysis, contextualization and addressee-related writing } \\
\text { associated with the source work is sensitized. }\end{array}$ \\
\hline
\end{tabular}

study regulations, care must be taken to build up knowledge of what scholarship and research are all about as specific cognitive processes. For theology, this task increases the challenge of further developing one's own methodology and making it transparent and learnable for the students. In teaching practice, however, research-oriented learning is hardly realized; at best, in this case, "practicing research" consists of imitation. It is no coincidence that the few approaches to real "self-research" focus on research-based questions. However, those who hold true to the educational ideals of institutions of higher learning as claimed by theology should accept this challenge, however.

The crucial test only occurs when the teaching projects and modules accept the issue of testing, search for forms of testing "in research" and develop criteria that meet the specific learning results of the combination of activity and subject matter (see Table 32.1). So far, the tests of the object of measurement are more closely related to reflection on the research process (also: "On Research"; cf. Reinmann in this volume). Without further development of the examinations, inquiry-based learning in theology remains a rather unstructured form, which sustains itself through the high commitment of individual teachers and students (cf. Hunze 2010, p. 258).

\section{References}

Blum, D./Bock, F./Henkelmann, A. (2015). Der hochschuldidaktische Königsweg? Forschendes Lernen in kirchenhistorischen Seminaren. In F. Bock/C. Handschuh/A. Henkelmann (Hrsg.), Kompetenzorientierte Kirchengeschichte. Hochschuldidaktische Perspektiven »nach Bologna", Theologie und Hochschuldidaktik; Bd. 6 (S. 91-114). Münster: Lit Verlag.

Freudenberger-Lötz, P. (2007). Theologische Gespräche mit Kindern. Untersuchungen zur Professionalisierung Studierender und Anstöße zu forschendem Lernen im Religionsunterricht. Stuttgart: Calwer.

Huber, L. (2014). Forschungsbasiertes, Forschungsorientiertes, Forschendes Lernen: Alles dasselbe? Das Hochschulwesen, $62(1+2), 32-39$.

Hunze, G. (2010). Die Gretchenfrage der Lehramtsausbildung: Wie hältst Du's mit der Praxis? oder: Wie verzahnen, was sich nicht trennen lassen dürfte? Engagement, 28 (4), 251-260.

Kalbheim, B. (2013). Zwischen akademischer Höhe und beruflicher Tiefe. Das didaktische Konzept »Forschendes Lernen« im theologischen Studium. Pastoraltheologische Informationen, 33, 193-206. 
Ludwig, J. (2011). Forschungsbasierte Lehre als Lehre im Format der Forschung. Potsdam: Universitätsverlag Potsdam. Retrieved 06 April 2016 from http://pub.ub.uni-potsdam.de/ volltexte/2011/4985/

Riegger, M. (2006). Wahrnehmen von Gottesbildern als forschend-evaluierendes Lernen. Reflexive Religionslehrerbildung an der Hochschule auf der Grundlage des symbolisch-kritischen Ansatzes. International Journal of Practical Theology, 10, 91-112.

Schmidl, S. M. (2012). Die Professionalisierung Studierender durch Reflexionsgespräche, Aufgezeigt am Beispiel der Forschungswerkstatt »Theologische Gespräche mit Jugendlichen«. Kassel: Univ. Press.

Zimmermann, M./Lenhard, H. (2015). Praxissemester Religion. Handwerkszeug für Berufsanfängerinnen und Berufsanfänger. Göttingen: Vandenhoeck \& Ruprecht.

Open Access This chapter is licensed under the terms of the Creative Commons AttributionNonCommercial-NoDerivatives 4.0 International License (http://creativecommons.org/licenses/bync-nd/4.0/), which permits any noncommercial use, sharing, distribution and reproduction in any medium or format, as long as you give appropriate credit to the original author(s) and the source, provide a link to the Creative Commons licence and indicate if you modified the licensed material. You do not have permission under this license to share adapted material derived from this chapter or parts of it.

The images or other third party material in this chapter are included in the chapter's Creative Commons licence, unless indicated otherwise in a credit line to the material. If material is not included in the chapter's Creative Commons licence and your intended use is not permitted by statutory regulation or exceeds the permitted use, you will need to obtain permission directly from the copyright holder.



